P-ISSN:

E-ISSN:

Email: ristansi@asia.ac.id

https://jurnal.stie.asia.ac.id/index.php/ristansi

\title{
PENGARUH CORPORATE GOVERNANCE DAN KINERJA PERUSAHAAN TERHADAP KETEPATAN WAKTU PENYAMPAIAN LAPORAN KEUANGAN BAGI PERUSAHAAN GO PUBLIC
}

DOI: doi.org// $\mathrm{xxxxx}$

\author{
Pipit Rosita Andarsari \\ Institut Teknologi Dan Bisnis Asia \\ Email : pipit.ra@asia.ac.id
}

$\begin{array}{ll}\text { InformasiArtikel } & \\ \text { TanggalMasuk } & \text { November } \\ & 17^{\text {th }}, 2020 \\ \text { TanggalRevisi } & \text { November } \\ & 29^{\text {th }}, 2020 \\ \text { Tanggalditerima } & \text { December } \\ & 11^{\text {th }}, 2020\end{array}$

Keywods:

board of

commissioners, audit committee, profitability ratio (ROA), leverage ratio (DER), leverage ratio (DER)

\begin{abstract}
:
This study aims to determine the effect of the board of commissioners, audit committees, profitability ratios, leverage ratios, and liquidity ratios on the timely delivery of financial statements. In this study the commissioner variable is proxied by the size of the board members, the audit committee is proxied by the size of the audit committee member, profitability ratio is proxied by ROA, leverage ratio is proxied by $D E R$, and liquidity ratio is proxied by $C R$. The research sample the basic and chemical sectors listed on the Indonesia Stock Exchange in 2016-2017 using a purposive sampling method. Research data sources secondary. Data analysis techniques logistic regression analysis. The results that the board of commissioners, audit committee, profitability ratio (ROA), and leverage ratio (DER) had no significant effect while the liquidity ratio (CR) had a significant effect on the timeliness of financial statement submission.
\end{abstract}

\section{Kata Kunci:}

Keyword: dewan komisaris, komite audit, profitability ratio ( $\mathrm{ROA})$, leverage ratio (DER), leverage ratio (DER)

\begin{abstract}
Abstrak:
Penelitian ini bertujuan untuk mengetahui pengaruh dewan komisaris, komite audit, profitability ratio, leverage ratio, dan liquidity ratio terhadap ketepatan waktu penyampaian laporan keuangan. Pada penelitian ini variabel dewan komisaris diproksikan dengan ukuran anggota dewan komisaris, komite audit diproksikan dengan ukuran anggota komite audit, profitability ratio diproksikan dengan ROA, leverage ratio diproksikan dengan DER, dan liquidity ratio diproksikan dengan CR. Sampel penelitian sektor dasar dan kimia yang terdaftar di BEI tahun 2016-2017 dengan menggunakan metode purposive sampling. Sumber data penelitian sekunder. Teknik analisis data analisis regresi logistik. Hasil penelitian bahwa dewan komisaris, komite audit, profitability ratio (ROA), dan leverage ratio (DER) tidak berpengaruh signifikan sedangkan liquidity ratio (CR) berpengaruh signifikan terhadap ketepatan waktu penyampaian laporan keuangan.
\end{abstract}




\section{PENDAHULUAN}

Perkembangan investasi begitu luar biasa saat ini. Meningkatnya jumlah perusahaan yang terdaftar di pasar modal menyebakan peningkatan permintaan atas penyediaan informasi yang relevan dan tepat waktu. Laporan keuangan merupakan salah satu faktor penting untuk pengambilan keputusan bagi para calon investor. Laporan keuangan merupakan salah satu media yang memberikan informasi dan pengukuran secara ekonomi mengenai kinerja perusahaan pada periode tertentu. Karena itu, ketepatan waktu pelaporan penyampaian lapoan keuangan merupakan salah satu elemen pokok dalam suatu laporan keuangan, dimana mengharuskan laporan keuangan tersebut disusun dan disajikan secepat mungkin untuk digunakan oleh para pengguna laporan keuangan. Ketepatan waktu merupakan hal penting dalam kaitannya dalam aspek transparasi pada tata kelola perusahaan (Abdullah, 2006) dan merupakan aspek bernilai tambah bagi peningkatan aspek finansial perusahaan.

Dalam Compliance theory, seseorang didorong untuk mematuhi peraturan yang berlaku, sama halnya dengan perusahaan wajib menyampaikan laporan keuangan secara tepat waktu karena selain merupakan suatu kewajiban perusahaan untuk menyampaikan laporan keuangan tepat waktu, juga akan sangat bermanfaat bagi para pengguna laporan keuangan (Sulistyo, 2010).

Ketepatan waktu merupakan istilah yang dipakai untuk menggambarkan bahwa data sebagai informasi disajikan tidak terlambat dan sesuai dengan waktu informasi itu diperlukan. Menurut Ikatan Akuntan Indonesia dalam Standar Akuntansi Indonesia (2009:1) Laporan keuangan merupakan bagian dari proses pelaporan keuangan. Laporan keuangan yang lengkap meliputi neraca, laporan laba rugi, laporan perubahan posisi keuangan (yang disajikan dalam berbagai cara, misalnya sebagai laporan arus kas atau laporan arus dana), catatan dan laporan lain, serta materi penjelasan yang merupakan bagian integral dari laporan keuangan.

Tuntutan akan kepatuhan terhadap ketepatan waktu dalam penyampaian laporan keuangan publik di Indonesia telah diatur dalam UU No. 8 tahun 1995 tentang Pasar Modal dan selanjutnya diatur dalam Keputusan Ketua Bapepam No. 80/PM/1996. Hal tersebut dimaksudkan untuk memudahkan pengawasan oleh pengawas pasar modal yaitu BAPEPAM-LK (Badan Pengawas Pasar Modal Dan Lembaga Keuangan) dan sebagai keterbukaan informasi yang dapat diakses oleh publik. Ketentuan tersebut juga dapat digunakan oleh investor dalam pengambilan keputusan investasi. Karena pergerakan ekonomi di Indonesia yang sangat dinamis maka Bapepam memperketat peraturan dengan dikeluarkannya Keputusan Ketua BAPEPAM Nomor KEP-431/BL/2012 tentang Kewajiban Penyampaian Laporan Keuangan Berkala. Peraturan baru tersebut mewajibkan perusahaan harus membuat laporan keuangan dan kemudian mendapatkan opini wajar dari auditor independen serta harus disampaikan kepada Bapepam selambat-lambatnya pada akhir bulan keempat (120 hari) setelah tanggal laporan keuangan. Dalam penyampaian laporan keuangan perusahaan, salah satu faktor penting adalah mengenai corporate governance dan kinerja perusahaan, dan hal tersebut berakibat pada ketepatan waktu penyampaian laporan.

Corporate governance merupakan tata kelola perusahaan yang menjelaskan hubungan pihak-pihak yang berpartisipasi dalam pengelolaan perusahaan dan kinerja perusahaan. Lemahnya corporate governance adalah adanya tindakan-tindakan yang mementingkan diri sendiri dengan mengabaikan kepentingan investor, maka akan menyebabkan jatuhnya harapan para investor tentang pengembalian atas investasi yang telah mereka tanamkan. Perusahaan yang telah menerapkan praktik corporate governance yang baik, seharusnya telah memenuhi prinsip-prinsip GCG antara lain 
fairness (kewajaran dan kesetaraan), transparency (transparan), accountability (akuntabilitas) dan responbility (responsibilitas). Menurut Beasley (1996) dalam Arif dan Bambang (2007) bahwa keempat komponen tersebut penting karena penerapan prinsip GCG secara konsisten terbukti dapat meningkatkan kualitas laporan keuangan. Dalam menjalankan komitmen-nya dalam melaksanakan praktek corporate governance yang baik dan dalam rangka mematuhi peraturan Pasar Modal, maka perusahaan akan segera menyampaikan informasi tentang keuangan perusahaan kepada para stakeholder untuk mempertanggungjawabkan kinerjanya secara transparan dan wajar, dan mengungkapkan informasi yang diwajibkan oleh peraturan perundang-undangan, yang dapat dipakai sebagai dasar pertimbangan untuk pengambilan keputusan oleh para stakeholder.

Dalam penelitian ini corporate governance diukur dengan menggunakan variabel dewan komisaris dan komite audit. Dewan komisaris menjadi mekanisme yang efektif untuk memonitor tindakan manajemen puncak atas nama pemegang saham (Kurniati, 2010). Dewan komisaris akan mengawasi proses penyelesaian laporan keuangan. Penelitian Tri dan Bambang (2007) menunjukkan bahwa dewan komisaris berpengaruh negatif dan signifikan secara statisitik terhadap ketepatan waktu penyampaian laporan keuangan. Selanjutnya penelitian Irene (2017) menunjukkan bahwa ukuran dewan komisaris berpengaruh secara positif terhadap ketepatan waktu corporate internet reporting.

Komite audit merupakan komite yang dibentuk oleh dewan direksi yang bertugas melaksanakan pengawasan independen atas proses laporan keuangan dan audit ekstern (Emirzon, 2007 dalam Savitri, 2010:56). Penelitian Febry (2017) menunjukkan bahwa komite audit berpengaruh negatif terhadap ketepatan waktu penyampaian laporan keuangan. Semakin banyaknya anggota komite audit mengindikasikan semakin banyaknya sumber daya yang dapat menyelesaikan permasalahan-permasalahan dalam pelaporan keuangan perusahaan sehingga dapat meningkatkan kualitas laporan keuangan yang kemudian dapat mempercepat pelaporan keuangan. Selanjutnya penelitian Roswita (2010) menunjukkan bahwa komite audit secara statistik berpengaruh signifikan terhadap ketepatan waktu pelaporan keuangan, maka dapat disimpulkan bahwa komite audit merupakan mekanisme corporate governance yang berpengaruh terhadap ketepatan waktu pelaporan keuangan.

Kinerja merupakan hasil akhir dari sebuah proses yang sistematis yang dilakukan untuk mencapai tujuan tertentu. Dalam penelitian ini alat ukur yang dilakukan untuk menilai kinerja perusahaan yaitu rasio profitabilitas, rasio leverage dan rasio likuiditas. Rasio profitabilitas menunjukkan keberhasilan perusahaan dalam menghasilkan keuntungan. Dengan semakin besar rasio profitabilitas maka semakin baik pula kinerja perusahaan sehingga perusahaan akan cenderung untuk memberikan informasi tersebut pada pihak lain yang berkepentingan. Dapat dikatakan bahwa profit merupakan berita baik (good news) bagi perusahaan. Penelitian Yusnianto (2014) menunjukkan bahwa Profitabilitas berpengaruh terhadap ketepatan waktu pelaporan laporan keuangan perusahaan. Jadi perusahaan yang mendapatkan laba akan semakin cepat melaporkan laporan keuangan. Hal ini juga sejalan dengan penelitian Mutiara (2015) yang menunjukkan bahwa profitabilitas berpengaruh positif signifikan terhadap ketepatan waktu penyampaian laporan keuangan pada perusahaan real estate and property yang terdaftar di BEI pada tahun 2011-2013.

Rasio leverage mengukur seberapa besar aset perusahaan dibiayai oleh hutang. Perusahaan yang mempunyai leverage tinggi berarti sangat tergantung pada pinjaman luar untuk membiayai aasetnya. Sedangkan perusahaan yang mempunyai leverage 
rendah lebih banyak membiayai investasinya dengan modal sendiri. Dengan demikian semakin tinggi leverage berarti semakin tinggi risiko karena ada kemungkinan bahwa perusahaan tersebut tidak bisa melunasi kewajiban hutangnya baik pokok maupun bunganya. Kesulitan keuangan merupakan berita buruk yang akan mempengaruhi kondisi perusahaan dimata publik, sehingga manajemen akan cenderung menunda publikasi laporan keuangannya. Debt to Equity Ratio berpengaruh terhadap ketepatan waktu penyampaian laporan keuangan ditunjukkan pada penelitian Yusnianto (2014) bahwa semakin besar tingkat debt to equity ratio akan semakin lambat perusahaan dalam melaporkan laporan keuangan.

Rasio likuiditas merupakan rasio yang digunakan untuk mengetahui kemampuan perusahaan dalam membayar kewajiban jangka pendek. Likuiditas suatu perusahaan sering ditunjukkan oleh rasio lancar yaitu dengan membandingkan aset lancar dengan kewajiban lancar.

Berdasarkan latar belakang diatas, judul penelitian ini adalah Pengaruh Good Corporate Governance dan Kinerja Perusahaan terhadap Ketepatan Waktu Penyampaian Laporan Keuangan bagi Perusahaan Go Public.

\section{METODE PENELITIAN}

Penelitian ini merupakan penelitian asosiatif kausal yang bertujuan mengetahui hubungan atau pengaruh antar dua variabel atau lebih (Bahri, 2018:17). Penelitian ini menguji pengaruh variabel independen yaitu dewan komisaris, komite audit, profitability ratio, dan leverage ratio terhadap variabel dependen yaitu ketepatan waktu penyampaian laporan keuangan. Populasi penelitian adalah perusahaan manufaktur yang terdaftar di Bursa Efek Indonesia periode 2016 - 2017. Metode pengambilan sampel secara purposive sampling dan sampel diambil berdasarkan suatu kriteria tertentu dan didapatkan sebanyak 44 perusahaan sampel terpilih.

Kriteria pemilihan sampel sebagai berikut:

1. Perusahaan manufaktur sektor industri dasar dan kimia yang terdaftar di Bursa Efek Indonesia selama tahun 2016 - 2017.

2. Perusahaan yang konsisten listing di Bursa Efek Indonesia selama tahun 2016 $-2017$.

3. Perusahaan yang menyajikan laporan keuangan lengkap di Bursa Efek Indonesia selama tahun 2016 - 2017.

4. Perusahaan yang memiliki informasi mengenai mekanisme corporate governance seperti dewan komisaris dan komite audit.

Jenis data dalam penelitian ini adalah data kuantitatif dengan metode pengumpulan data adalah dokumentasi berupa laporan keuangan tahunan perusahaan manufaktur yang terdaftar di Bursa Efek Indonesia dan ICMD tahun 2016 - 2017, dan artikel-artikel yang berkaitan serta dari berbagai literatur lain.

\section{Teknik Analisis Data dan Uji Hipotesis}

1. Analisis Statistik Deskriptif

Menurut Bahri (2018:298) statistik deskiprif adalah statistik yang mempelajari tata cara penyusunan dan penyajian data yang dikumpulkan dalam suatu riset dengan tujuan mendapatkan gambaran atau mendeskripsikan sekumpulan data hasil pengamatan sehingga mudah dipahami, dibaca, dan digunakan sebagai informasi. Alat analisis yang digunakan merupakan rata-rata (mean) dan standar deviasi.

2. Analisis Regresi Logistik

Pengujian hipotesis dilakukan secara uji multivariate dengan menggunakan regresi logistik. Regresi logistik digunakan untuk menguji apakah variabel-variabel dewan 
komisaris, komite audit, profitability ratio, leverage ratio dan liquidity ratio mempengaruhi ketepatan waktu penyampaian laporan keuangan. Regresi logistik sebenarnya mirip dengan analisis deskriminan yaitu menguji apakah probabilitas terjadinya variabel terikat (dependen) dapat diprediksi dengan variabel bebasnya (independen). Namun demikian, asusmsi multivariate normal distribution tidak dapat dipenuhi karena variabel bebas (independen) merupakan campuran antara variabel kontinyu (metrik) dan kategorial (non-metrik). Dalam hal ini dapat dianalisis dengan logistic regression karena tidak perlu asumsi normalitas data pada variabel bebasnya (Ghozali, 2016:321).

Prosedur analisis data yang diperhatikan sebelum melakukan analisis pengujian regresi logistik, adalah:

a. Menilai Kelayakan Model Regresi (Goodness of Fit Test)

Dalam pengujian kelayakan model regresi logistik dapat dilakukan dengan menggunakan Goodness of Fit Test yang diukur dengan nilai Chi-Square pada bagian bawah uji Hosmer and Lemeshow. Nilai goodness of fit test yang diukur dengan nilai chi square pada bagian bawah uji Hosmer and Lemeshow jika probabilitas lebih dari 0,05 atau 5\% maka hipotesis diterima, sebaliknya jika probabilitas kurang dari 0,05 atau 5\% maka hipotesis ditolak.

b. Menguji Keseluruhan Model Fit (Overall Model Fit Test)

Perhatikan angka -2 Log Likelihood (LL) pada awal (blockNumber $=0$ ) dan angka -2 Log Likelihood pada block Number $=1$. Jikaterjadi penurunan angka -2 Log Likelihood (block Number $=0$ - blockNumber $=1$ ) menunjukkan model regresi yang baik. Log Likelihoodpada logistic regression mirip dengan pengertian "sum of squarederror" pada model regresi sehingga penurunan Log Likelihoodmenunjukkan model regresi yang baik.

c. Menguji Signifikansi Model

Signifikansi model regresi dinilai dengan menggunakan Omnibus Test of Model Coefficients. Nilai signifikasi pada tabel Omnibus Test of Model Coefficients jika probabilitas lebih dari 0,05 atau 5\% maka hipotesis ditolak, sebaliknya jika probabilitas kurang dari 0,05 atau 5\% maka hipotesis diterima. Besarnya kemampuan variabel bebas dalam menjelaskan varian variabel terikat bisa dilihat pada tabel Model Summary dengan memperhatikan nilai Nagelkerke R Square.

\section{Uji Hipotesis}

Uji hipotesis menggunakan tingkat signifikansi sebesar 5\%, kriteria penerimaan dan penolakan hipotesis didasarkan pada significant p-value (probabilitas value) dan nilai wald. Jika p-value (significant) $>(5 \%)$ dan nilai wald < dari chi square tabel, maka hipotesis alternatif ditolak. Sebaliknya jika p-value $<(5 \%)$ dan nilai wald $>$ chi square tabel, maka hipotesis diterima.

\section{HASIL PENELITIAN}

\section{Analisis Statistik Deskriptif}

Berikut statistik secara umum dari seluruh data yang digunakan.

Tabel 1.

Statistik Deskriptif

\begin{tabular}{|l|c|r|r|r|r|}
\hline & $\mathrm{N}$ & \multicolumn{1}{|c|}{ Minimum } & Maximum & \multicolumn{1}{c|}{ Mean } & Std. Deviation \\
\hline Dewan Komisaris & 88 & 2,0 & 8,0 & 4,148 & 1,7056 \\
Komite Audit & 88 & 3,0 & 5,0 & 3,148 &, 4431 \\
Profitability ratio (ROA) & 88 & $-29,91$ & 15,77 & 2,4688 & 6,52476 \\
Leverage Ratio (DER) & 88 & $-1019,00$ & 16219,00 & 383,8068 & 1984,60468
\end{tabular}


\begin{tabular}{|l|l|l|l|l|l|} 
Liquidity Ratio (CR) & 88 & 8,92 & 1516,46 & 225,3989 & 220,27081 \\
Valid N (listwise) & 88 & & & & \\
\hline
\end{tabular}

Sumber: Lampiran 4 diolah, 2020

Berdasarkan tabel 1, maka dapat dijelaskan sebagai berikut:

1. Variabel dewan komisaris memiliki nilai terendah sebesar 2, nilai tertinggi 8, nilai rata-rata sebesar 4,148 dan standart deviasi sebesar 1,7056.

2. Variabel komite audit memiliki nilai terendah sebesar 3, nilai tertinggi 5, nilai rata-rata sebesar 3,148 dan standart deviasi sebesar 0.4431 .

3. Variabel profitability ratio memiliki nilai terendah sebesar $-29,91$, nilai tertinggi 15,77 , nilai rata-rata 2,4688 dan standart deviasi sebesar 6,52476.

4. Variabel leverage ratio memiliki nilai terendah sebesar -1019 , nilai tertinggi 16219, nilai rata-rata 383,8068, dan standart deviasi sebesar 1984,60468.

5. Variabel liquidity ratio memiliki nilai terendah sebesar 8,92 , nilai tertinggi 1516,46, nilai rata-rata 225,3989 dan standart deviasi sebesar 220,27081.

2. Analisis Regresi Logistik

a. Menilai Kelayakan Model Regresi (Goodness Fit of Test)

Uji Hosmer and Lemeshow digunakan untuk menguji hipotesis bahwa data empiris cocok atau sesuai dengan model (tidak ada perbedaan antara model dengan data sehingga model dikatakan fit). Berdasarkan pengujian Hosmer and Lemeshow yang telah dilakukan, maka diperoleh hasil sebagai berikut:

Tabel 2

Hosmer And Lemeshow Test

\begin{tabular}{|l|l|l|l|}
\hline Step & Chi-square & Df & Sig. \\
\hline 1 & 3,056 & 8 &, 931 \\
\hline
\end{tabular}

Sumber: Lampiran 5 diolah, 2020

Berdasarkan hasil pengujian di atas, nilai dari Chi-square pada uji Hosmer and Lemeshow sebesar 3,056 pada df 8 dimana lebih kecil dari chi square tabel yaitu 15,507 dengan tingkat signifikansi sebesar 0,931. Besarnya nilai signifikansi tersebut $>0,05$, sehingga model regresi layak dipakai untuk analisis selanjutnya, karena tidak ada perbedaan antara klasifikasi yang diprediksi dengan klasifikasi yang diamati. Pada tabel klasifikasi, bagian kolom merupakan nilai prediksi dari variabel dependen. Nilai 0 untuk perusahaan tidak tepat waktu dan nilai 1 untuk perusahaan tepat waktu dalam penyampaian laporan keuangan. Pada bagian baris menunjukkan nilai observasi penelitian yang sesungguhnya dari dari perusahaan yang tidak tepat waktu dan tepat waktu dalam penyampaian laporan keuangan. Berdasarkan tabel klasifikasi yang telah dilakukan maka diperoleh hasil sebagai berikut:

Tabel 3

Tabel Klasifikasi

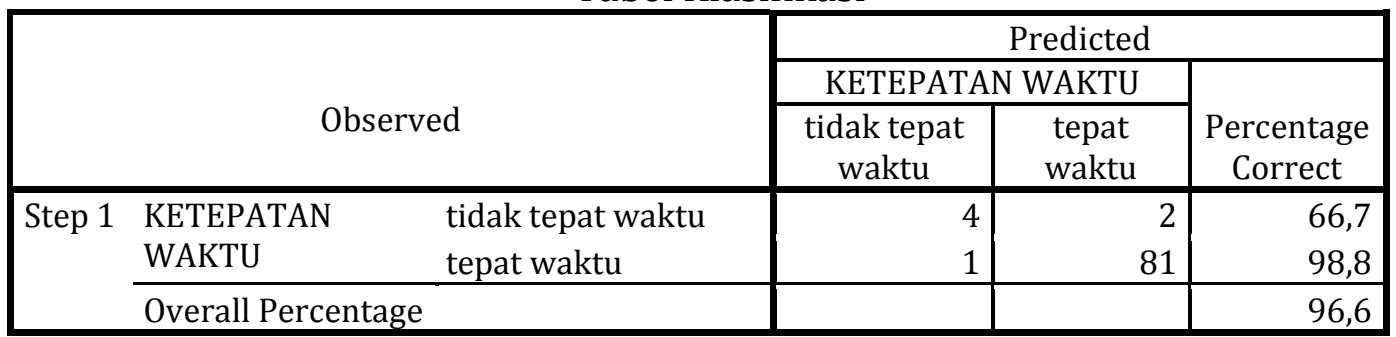

a. The cut value is ,500

Sumber: Lampiran 5 diolah, 2020 
Berdasarkan tabel 3 dapat dilihat bahwa dari 6 perusahaan yang tidak tepat waktu setelah diprediksi dengan analisis regresi logistik terdapat 2 perusahaan yang berpidah ke tepat waktu atau dengan kata lain sebesar $66,7 \%$ dari 6 perusahaan yang memiliki kategori tidak tepat waktu, kemudian dari 82 perusahaan yang tepat waktu setelah diprediksi terdapat 1 perusahaan yang berubah menjadi kategori tidak tepat waktu atau dengan sebesar 98,8\% dari 82 perusahaan yang tepat waktu. berdasarkan hasil analisis tersebut maka secara umum model yang diperoleh dapat diandalkan dalam memprediksi sebesar 96,6\%.

b. Menguji Keseluruhan Model Fit (Overall Model Fit Test) Pada uji Overall Model Fidapat dilihat pada tabel Iteration History, pengujian dilakukan dengan membandingkan nilai antara -2 log likelihood pada awal (block 0) dengan nilai -2 log likelihood pada akhir (block 1 step 1). Berdasarkan pengujian Overall Model Fit diperoleh hasil sebagai berikut:

Tabel 4

Overall Model Fit

\begin{tabular}{|c|l|}
\hline Block & -2 Log likelihood \\
\hline 0 & 43,808 \\
\hline 1 & 15,444 \\
\hline
\end{tabular}

Sumber: Lampiran 5 diolah, 2020

Berdasarkan tabel di atas, nilai -2 Log Likelihood awal (Block Number $=0$ ) adalah sebesar 43,808, sedangkan nilai -2 Log Likelihood akhir (Block Number $=1$ ) sebesar 15,444. Dari nilai tersebut berarti -2 Log Likelihood awal (Block Number $=0$ ) mengalami penurunan jika dibandingkan dengan -2 Log Likelihood akhir (Block Number =1), artinya dengan menanbah kelima variabel kedalam penelitian tersebut akan memperbaiki model fit dan menunjukkan model yang dihipotesiskan fit dengan baik.

C. Menguji Signifikansi Model

Menguji signifikansi model menggunakan uji Omnibus menyajikan uji serentak (simultan) semua koefisien variabel pada regresi logistik. Dengan kata lain yaitu untuk melihat bagaimana pengaruh semua variabel independen secara bersama terhadap variabel dependen. Berdasarkan pengujian Omnibus yang telah dilakukan, diperoleh hasil sebagai berikut:

Tabel 5

Omnibus Test

\begin{tabular}{|ll|l|l|l|}
\hline & & Chi-square & Df & Sig. \\
\hline Step 1 & Step & 28,364 & 5 &, 000 \\
& Block & 28,364 & 5 &, 000 \\
& Model & 28,364 & 5 &, 000 \\
\hline
\end{tabular}

Sumber: Lampiran 5 diolah, 2020

Berdasarkan tabel nilai chi square model adalah sebesar 28,364 dengan nilai p-value sebesar 0,000, karena nilai signifikansi lebih kecil dari $\alpha(5 \%)$ sehingga bisa disimpulkan bahwa variabel independen (dewan komisaris, komite audit, profitability ratio (ROA), leverage ratio (DER), dan liquidity ratio (CR)) secara simultan berpengaruh signifikan terhadap variabel depeden (ketepatan waktu) dan minimal ada satu variabel independen yang berpengaruh.

Tabel 6

Model Summary

\begin{tabular}{|l|l|l|l|}
\hline Step & $\begin{array}{l}-2 \text { Log } \\
\text { likelihood }\end{array}$ & $\begin{array}{l}\text { Cox \& Snell R } \\
\text { Square }\end{array}$ & $\begin{array}{l}\text { Nagelkerke R } \\
\text { Square }\end{array}$ \\
\hline 1 & $15,444^{\mathrm{a}}$ &, 276 &, 703 \\
\hline
\end{tabular}


Berdasarkan tabel di atas, dapat diketahui bahwa nilai Nagelkerke R Square sebesar 0,703 . Artinya variabel dependen dapat dijelaskan oleh variabel independen sebesar $70,3 \%$. Dengan kata lain, ketepatan waktu pelaporan dapat dijelaskan oleh dewan komisaris, komite audit, profitability ratio (ROA), leverage ratio (DER) dan liquidity ratio (CR) sebesar 70,3\%, dan akan dijelaskan oleh variabel lain diluar penelitian ini sebesar $29,7 \%$.

\section{Uji Hipotesis}

Pengujian hipotesis pada regresi logistik terdapat pada tabel uji variables in the equation, untuk menguji bagaimana pengaruh masing-masing variabel independen secara sendiri-sendiri (parsial) terhadap variabel dependen. Berikut hasil uji variables in the equation:

Tabel 7

Uji Variables In The Equation

\begin{tabular}{|c|c|c|c|c|c|c|c|}
\hline & & B & S.E. & Wald & Df & Sig. & $\operatorname{Exp}(B)$ \\
\hline \multirow{6}{*}{$\begin{array}{l}\text { Step } \\
1^{\text {a }}\end{array}$} & DK & $-1,072$ & 606 & 3,131 & 1 & ,077 & ,342 \\
\hline & KA & 16,457 & 8490,283 &, 000 & 1 & ,998 & 14030682,185 \\
\hline & ROA & -,082 & 210, & 153, & 1 & 696, & ,921 \\
\hline & DER & 000 & ,000 & ,416 & 1 & ,519 & 1,000 \\
\hline & $\mathrm{CR}$ & ,070 & ,031 & 5,111 & 1 & 024 & 1,072 \\
\hline & Constant & $-48,270$ & 25470,849 &, 000 & 1 & ,998 &, 000 \\
\hline
\end{tabular}

Sumber: Lampiran 5 diolah, 2020

Berdasarkan tabel 7 maka dapat diartikan sebagai berikut:

1. Variabel Dewan komisaris

Nilai statistik wald variabel DK tersebut lebih kecil dari nilai chi-square $(3,131<3,841)$ atau $p$-value tersebut lebih besar dari $\alpha(0,077>0,050)$ menunjukkan bahwa variabel dewan komisaris tidak berpengaruh signifikan terhadap variabel Y (ketepatan waktu).

2. Variabel Komite audit

Nilai statistik wald variabel KA tersebut lebih kecil dari nilai chi-square $(0,000<3,841)$ atau $p$-value tersebut lebih besar dari $\alpha(0,998>0,050)$ menunjukkan bahwa variabel KA tidak berpengaruh signifikan terhadap variabel Y (ketepatan waktu).

3. Variabel profitability ratio (ROA)

Nilai statistik wald variabel ROA tersebut lebih kecil dari nilai chi-square $(0,153<3,841)$ atau $p$-value tersebut lebih besar dari $\alpha(0,696>0,050)$ menunjukkan bahwa variabel ROA tidak berpengaruh signifikan terhadap variabel Y (ketepatan waktu).

4. Variabel leverage ratio (DER)

Nilai statistik wald variabel DER tersebut lebih kecil dari nilai chi-square $(0,416<3,841)$ atau $p$-value tersebut lebih besar dari $\alpha(0,519>0,050)$ menunjukkan bahwa variabel DER tidak berpengaruh signifikan terhadap variabel Y (ketepatan waktu).

5. Variabel liquidity ratio (CR)

Nilai statistik wald variabel CR tersebut lebih besar dari nilai chi-square $(5,111>3.841)$ atau $p$-value tersebut lebih kecil dari $\alpha(0,024<0,050)$ 
menunjukkan bahwa variabel CR berpengaruh signifikan terhadap variabel Y (ketepatan waktu).

\section{PEMBAHASAN}

\section{Pengaruh Dewan Komisaris Terhadapan Ketepan Waktu Penyampaian Laporan Keuangan}

Berdasarkan uji hipotesis secara persial hasil menunjukkan bahwa pengaruh dewan komisaris terhadap ketepatan penyampaian laporan keuangan ditolak sehingga dewan komisaris yang diproksikan dengan jumlah anggota dewan komisaris tidak berpengaruh signifikan terhadap ketepatan waktu penyampaian laporan keuangan. Hal ini menunjukkan jumlah dewan komisaris yang sedikit belum tentu dapat memberikan masukan atau nasehat dengan cepat dalam mengambil keputusan terhadap perusahaan, dan sebaliknya ,jumlah dewan komisaris yang banyak bisa jadi semakin rumit dalam pengambilan keputusan untuk menyampaikan laporan keuangan secara tepat waktu. Hal ini dibuktikan dengan jumlah 88 sampel laporan keuangan perusahaan menyatakan bahwa dewan komisaris memiliki nilai minimum 2 orang anggota dan maksimum 8 orang anggota, perusahaan tersebut sama-sama melaporkan laporan keuangan secara tepat waktu.

\section{Pengaruh Komite Audit Terhadap Ketepatan Waktu Penyampaian Laporan Keuangan}

Berdasarkan uji hipotesis secara persial hasil menunjukkan bahwa jumlah komite audit tidak berpengaruh signifikan terhadap ketepatan waktu penyampaian laporan keuangan. Hal ini karena komite audit belum secara maksimal melaksanakan fungsinya sehingga jumlah anggota yang besar tidak berpengaruh terhadap ketepatan waktu (timeliness) pelaporan keuangan. Jumlah anggota komite audit yang terlalu banyak dianggap dapat kehilangan fokus dan kurang berkontribusi dalam melaksanakan tugasnya, sedangkan jumlah anggota komite audit yang terlalu sedikit dianggap memiliki kekurangan dalam hal keterampilan dan pengetahuan. Dalam data yang telah diteliti rata-rata jumlah komite audit hanya 3 orang anggota yang berakibat kurangnya pengawasan terhadap kegiatan serta masalah yang berkaitan dalam laporan keuangan perusahaan akibatnya karakteristik komite audit tidak berpengaruh signifikan terhadap ketepatan waktu penyampaian laporan keuangan perusahaan. Hasil penelitian ini didukung dengan penelitian Mirani (2014) yang mengatakan bahwa komite audit belum secara maksimal melaksanakan tugasnya dan hanya bersifat pemenuhan kewajiban saja sehingga keanggotaan yang besar justru akan menurunkan kinerja komite audit.

\section{Pengaruh Profitability Ratio Terhadap Ketepatan Waktu Penyampaian Laporan Keuangan}

Hasil uji hipotesis secara persial menunjukkan bahwa profitability ratio yang diproksikan dengan ROA tidak berpengaruh signifikan terhadap ketepatan waktu penyampaian laporan keuangan. Hal ini menunjukkan bahwa tinggi rendahnya profitabilitas suatu perusahaan tidak mempengaruhi ketepatan waktu penyampaian laporan keuangan. Laporan keuangan tahunan merupakan salah satu jenis informasi yang dibutuhkan dan berpengaruh bagi pihak investor. Bagi investor pengumuman adanya laba dari perusahaan merupakan berita baik untuk menginvestasikan modal, apabila berinvestasi pada perusahaan tersebut maka akan diperolehnya laba dan beranggapan bahwa kinerja perusahaan dalam keadaan baik. Namun, beberapa perusahaan yang memiliki kemampuan dalam menghasilkan laba akan menahan laba tersebut untuk kepentingan investasi perusahaan, sehingga perusahaan yang memiliki 
laba yang tinggi akan menginvestasikan sebagian labanya untuk perusahaan tersebut. Hal ini tidak membuktikan bahwa perusahaan yang memperoleh laba tinggi akan melaporkan laporan keuangannya tepat waktu dan sebaliknya perusahaan yang mengalami laba rendah akan melaporkan laporan keuangannya terlambat. Sesuai dengan data penelitian bahwa perusahaan dengan kode TBMS tahun 2016 yang memiliki profitabilitas tinggi yaitu sebesar 5,57\% dalam penyampaian laporan keuangannya terlambat dan sebaliknya perusahaan dengan kode APLI tahun 2017 yang memiliki profitabilitas rendah yaitu $-0,33 \%$ penyampaian laporan keuangannya tepat waktu. Hal ini terbukti dengan penelitian Yuliana (2017) bahwa profitability ratio tidak berpengaruh signifikan terhadapan ketepatan waktu penyampaian laporan keuangan.

\section{Pengaruh Leverage Ratio Terhadap Ketepatan Waktu Penyampaian Lapran Keuangan}

Hasil uji hipotesis menunjukkan bahwa rasio leverage yang diproksikan dengan DER tidak berpengaruh signifikan terhadap ketepatan waktu penyampaian laporan keuangan. Hal ini menunjukkan bahwa tinggi rendahnya leverage suatu perusahaan tidak mempengaruhi ketepatan waktu penyampaian laporan keuangan. Perusahaan menganggap bahwa permasalahan hutang bukanlah suatu berita yang buruk selama masih ada cara dalam proses penyelesaiannya. Hal ini karena leverage atau hutang yang dimiliki perusahaan tidak terlalu berdampak buruk, leverage bisa menjadi penyeimbang struktur modal perusahaan. Perusahaan yang mempunyai leverage tinggi dikarenakan perusahaan tersebut akan melakukan ekspansi secara luas untuk meningkatkan pangsa pasar, hal tersebut merupakan hal positif sehingga perusahaan tetap akan melaporkan laporan keuangannya tepat waktu. Selain itu, perusahaan yang mempunyai leverage tinggi akan tetap melaporkan laporan keuangannya tepat waktu bertujuan agar pihak kreditor dapat mengetahui kinerja dan kemampuan perusahaan dalam membayar pinjaman, jika menunda pelaporan maka akan mengurangi kepercayaan kreditor terhadap perusahaan dalam membayar hutang. Hal ini tidak membuktikan bahwa perusahaan yang mempunyai leverage tinggi akan melaporkan laporan keuangannya terlambat dan sebaliknya perusahaan yang mempunyai leverage rendah akan melaporkan laporan keuangannya tepat waktu. Perusahaan yang mempunyai tingkat leverage tinggi maupun rendah mempunyai kecendurungan yang sama dalam melaporkan laporan keuangan dengan tepat waktu maupun terlambat. Sesuai dengan data penelitian bahwa perusahaan dengan kode CTBN tahun 2017 dan MYRX tahun 2017 dengan nilai leverage sebesar 0,42\% dan 0,44\%, dengan leverage yang hampir sama perusahaan kode CTBN melaporkan laporan keuangan secara tepat waktu dan perusahaan kode MYRX melaporkan laporan keuangan secara terlambat. Hal ini terbukti dengan penelitian Adi (2015) bahwa rasio leverage tidak berpengaruh signifikan terhadapan ketepatan waktu penyampaian laporan keuangan.

\section{Pengaruh Liquidity Ratio Terhadap Ketepatan Waktu Penyampaian Laporan Keuangan}

Berdasarkan uji hipotesis, menunjukkan bahwa raso likuiditas yang diproksikan dengan current ratio berpengaruh signifikan terhadap ketepatan waktu penyampaian laporan keuangan. Hal ini membuktikan bahwa perusahaan yang mempunyai likuiditas yang tinggi akan mempercepat penyampaian laporan keuangannya dibandingkan dengan perusahaan yang mempunyai likuiditas yang rendah. Tingkat likuiditas yang tinggi pada suatu perusahaan menunjukkan bahwa perusahaan tersebut mempunyai kemampuan yang tinggi untuk memenuhi kewajiban jangka pendeknya. Hal ini merupakan berita yang baik bagi pemakai laporan keuangan 
terutama calon investor yang akan menginvestasikan dananya dan para kreditor, sehingga perusahaan akan lebih tepat waktu dalam penyampaian laporan keuangannya. Sesuai dengan data penelitian bahwa perusahaan dengan kode INTP tahun 2016 mempunyai nilai likuiditas sebesar 452,5\% melaporkan laporan keuangannya tepat waktu, perusahaan dengan kode SMCB tahun 2016 mempunyai nilai likuiditas sebesar 45,94\% melaporkan laporan keuangannya terlambat.

\section{KESIMPULAN}

1. Hasil penelitian menunjukkan dewan komisaris, komite audit, rasio profitabilitas, dan rasio leverage tidak berpengaruh signifikan terhadap ketepatan waktu penyampaian laporan keuangan sedangkan rasio likuiditas berpengaruh signifikan terhadap ketepatan waktu penyampaian laporan keuangan. Hasil rasio likuiditas yang tinggi menjadi motivasi untuk mempercepat waktu penyampaian laporan keuangan perusahaan, sedangkan jika hasilnya rendah maka akan memperlambat waktu penyampaian laporan keuangan perusahaaan. Penelitian ini hanya memilih sektor dasar dan kimia, sehingga hasilnya tidak mampu digeneralisasikan untuk perusahaan lain diluar sektor tersebut. Untuk menyempurnakan penelitian selanjutnya ,maka bisa dengan memperluas sampel penelitian selain sektor dasar dan kimia agar hasil penelitian dapat digeneralisasikan pada sektor yang lain.

\section{REFERENSI}

Abdullah, S. N. 2006. Board Composition, Audit Committee And Timeliness Of Corporate Financial Reports In Malaysia, Ukraine Journal Corporate Ownership And Control, Vol. 4, No.3, Hal. 33-45.

Anggraini, Febry. 2017. Pengaruh Mekanisme Corporate Governance dan Kinerja Keuangan Terhadap Financial Reporting Lag, Jurnal Ilmu dan Riset Akuntansi, Vol. 6, No. 1, hal 102-119.

Arif dan Bambang. 2007. Mekanisme Corporate Governance,Manajemen Laba dan Kinerja Keuangan (Studi pada Perusahaan Go Publik Sektor Manufaktur). Simposium Nasional Akuntansi X.

Bahri, Syaiful. 2018. Metodologi Penelitian Bisnis Lengkap Dengan Teknik Pengolahan Data SPSS. Edisi Pertama, Penerbit Andi, Yogyakarta.

Chaterine, Irene. 2017. Pengaruh Corporate Governance terhadap Ketepatan Waktu Corporate Internet Reporting (Studi Empiris pada Perusahaan yang Terdaftar di Bursa Efek Indonesia. Skripsi. Fakultas Ekonomi Universitas Sanata Dharma Yogyakarta.

Dinanti, Mutiara. 2015. Pengaruh Solvabilitas, Profitabilitas, Kualitas Auditor dan Ukuran Perusahaan Terhadap Ketepatan Waktu Penyampaian Laporan Keuangan pada Perusahaan Real Estate and Property yang Terdaftar di Bursa Efek Indonesia Periode Tahun 2011-2013. Skripsi. Fakultas Ekonomi Universitas Negeri Malang.

Emirzon, J. 2007. Good Corporate Governance. Lengge Printika, Yogyakarta.

Gunarsih, Tri dan Hartadi, Bambang. 2007. Struktur Corporate Governance dan Ketepatan Waktu Penyampaian Laporan keuangan: Studi pada Perusahaan Jasa di BEI, Jurnal Keuangan dan Perbankan, Vol. 12, No. 2, hal. 204-216.

Ghozali, Imam. 2016. Aplikasi Analisis Multivariete dengan Program IBM SPSS 23. Edisi 8, Badan Penerbit Universitas Diponegoro, Semarang

Ikatan Akuntan Indonesia. 2012. Standar Akuntansi Keuangan Per 1 Juni 2012. Ikatan Akuntan Indonesia, Jakarta. 
Purbasari, Mirani. 2014. Analisis Pengaruh Karakteristik Komite Audit dan Profitabilitas Terhadap Timeliness Laporan Keuangan (Studi Empiris pada Perusahaan Manufaktur yang Terdaftar di BEI),Jurnal Akuntansi Fakultas Ekonomika dan Bisnis Universitas Diponegoro, Vol 3, No.3, Hal 1-12.

Savitri, Roswita. 2010. Pengaruh Mekanisme Corporate Governance Terhadap Ketepatan Waktu Pelaporan Keuangan:Studi pada Perusahaan Manufaktur di BEI. Skripsi. Fakultas Ekonomi Universitas Diponegoro. Semarang.

Sulistyo, W. A. N. 2010. Analisis Faktor-faktor yang Berpengaruh Terhadap Ketepatan Waktu Penyampaian Laporan Keuangan pada Perusahaan yang Listing di Bursa Efek Periode 2006-2008. Skripsi. Universitas Diponegoro. Semarang.

Wirawan, Adi. 2015. Pengaruh Leverage, Profitabilitas, dan Good Corporate Governance Terhadap Ketepatan Waktu Pelaporan Keuangan Pada Perusahaan Manufakturyang Terdaftar BEI Tahun 2012-2013. Skripsi. Fakultas Ekonomi Universitas Negeri Malang.

www.idx.co.id

www.wikipedia.co.id

Yuliana. 2017. Pengaruh Kinerja Keuangan, Size dan Reputasi KAP Terhadap Ketepatan Waktu Pelaporan Keuangan, Jurnal Ilmu dan Riset Akuntansi, Vol. 6, No. 1, hal 31-45.

Yusnianto. 2014. Pengaruh Karakteristik Perusahaan Terhadap Ketepatan Waktu Penyampaian Laporan Keuangan pada Perusahaan Manufaktur yang Terdaftar di BEI pada Tahun 2011-2012. Skripsi. Fakultas Ekonomi Universitas Negeri Malang 